\title{
8OHdG Levels in Brain Do Not Indicate Oxidative DNA Damage in Alzheimer's Disease
}

\author{
J. M. TE KOPPELE, ${ }^{11}$ P. J. LUCASSEN, $\dagger$ A. N. SAKKEE, ${ }^{*}$ J. G. VAN ASTEN,${ }^{*}$ R. RAVID, $\dagger$ D. F. SWAAB $\dagger$ \\ AND C. F. A. VAN BEZOOIJEN*2 \\ *TNO Prevention and Health, Division of Vascular and Connective Tissue Research, Gaubius Laboratory, P.O. Box \\ 2215, 2301 CE Leiden, The Netherlands \\ $\dagger$ Netherlands Institute for Brain Research, Meibergdreef 33, 1105 AZ, Amsterdam ZO, The Netherlands
}

Received 19 October 1995; Accepted 15 May 1996

\begin{abstract}
TE KOPPELE, J. M., P. J. LUCASSEN, A. N. SAKKEE, J. G. VAN ASTEN, R. RAVID, D. F. SWAAB AND C. F. A. VAN BEZOOIJEN. 8OHdG levels in brain do not indicate oxidative DNA damage in Alzheimer's Disease. NEUROBIOL AGING 17(6) 819-826, 1996.-Alccumulation of oxidative DNA damage has been proposed to underlie aging and neurodegenerative diseases such as Alzheimer's Disease (AD). The DNA adduct 8-hydroxy-2'-deoxyguanosine (8OHdG) is considered a good indicator of oxidative DNA damage. To investigate whether this type of DNA damage is involved in AD etiology, 80HdG levels were determined in postmortem human brain tissue of controls and AD patients (in frontal, occipital, and temporal cortex and in hippocampal tissue). Parametric studies in rat revealed no influences of postmortem delay, repeated freezing/thawing or storage time. In human brain, approximately two $8 \mathrm{OHdG}$ molecules were present per $10^{5} 2^{\prime}$-deoxyguanosines. In AD patients and controls, $8 \mathrm{OHdG}$-levels were not related to age, sex, or brain region. Also, no differences were found between controls and AD patients. It was concluded that $80 \mathrm{OHdG}$ in nuclear DNA, although present throughout the brain in fairly high amounts, does not accumulate with age, nor does it appear to be involved in AD. More detailed studies are required to extend this conclusion to other types of oxidative damage. Copyright 11996 by Elsevier Science Inc.
\end{abstract}

Alzheimer's Disease Aging DNA damage HPLC-ECD $\quad$ Oxygen radicals $\quad$ 8-Hydroxy-2'-deoxyguanosine
Human brain Cortex Hippocampus

ONE of the theories on the etiology of normal aging and Alzheimer's disease $(\mathrm{AD})$ involves the accumulation of DNA damage $(18,25,43)$. Oxidative damage to proteins and DNA occurs as a consequence of the generation of oxidants such as superoxide anions, hydrogen peroxide, and hydroxyl radicals, byproducts of normal cellular metabolism $(1,9,15)$. Several changes in AD tissue, such as condensed chromatin (29), increased peroxidation (50), and membrane abnormalities (55) are consistent with the expected effects of reactive oxygen species. Furthermore, free oxygen radicals have been suggested to be involved in $\beta$-amyloidosis (17).

To maintain the integrity of the genome, cells are equipped with antioxidant defense mechanisms and DNA repair systems $(15,18,21,45)$. It has been hypothesized that some neurodegenerative diseases may be related to elevated levels of DNA damage as a consequence of a defect in DNA repair or a decrease in antioxidant capacity $(4,13,18,40,41,45,54)$. For instance, diminished DNA repair capacity was shown to be involved in Cockayne's syndrome $(28,52)$ and $\mathrm{AD}(5,40,42,49)$. In addition, a twofold higher number of DNA single strand breaks was observed in the cortex of $\mathrm{AD}$ patients as compared to controls (36), indicating that DNA damage may indeed play a role in AD.

The brain is expected to be particularly prone to oxygen radical damage $(20,23)$ because of its relatively high oxygen consumption and the high concentrations of some trace metals, important catalysts of oxidative damage, in certain brain areas $(7,10,11,19)$. Oxygen free radicals, together with metals like iron or copper, are known to cause peroxidation and subsequent DNA lesions such as the oxidatively modified nucleoside 8-hydroxy-2'-deoxyguanosine [8OHdG; $(2,6,15,35)]$. $8 \mathrm{OHdG}$ is considered to be a useful biomarker of oxidative DNA damage because its formation can also be induced by oxidative stress in vitro $(14,47)$. In addition, $80 \mathrm{HdG}$ has been shown to accumulate with age in several tissues including brain $(16,24,26,34)$, and it can be measured relatively easily with high sensitivity by HPLC with electrochemical detection [HPLC. ECD; $(22,31,46,47)]$.

In the present study, we describe methodological adjustments of existing HPLC-ECD assays to determine 8OHdG levels in small autopsy specimens of human brain tissue. Parametric investigations were performed with respect to storage time, postmortem delay, and repeated freezing/thawing of brain tissue on $80 \mathrm{HdG}$ levels in brain DNA. Subsequently, the assay was applied on cortical areas and hippocampal tissue of Alzheimer patients and control subjects to determine whether 8 OHdG levels do support involvement of oxidative DNA damage in $\mathrm{AD}$ etiology.

\footnotetext{
${ }^{1}$ To whom requests for reprints should be addressed.

${ }^{2}$ Present address: Department of Public Health, Erasmus University Rotterdam, P.O. Box 1738, 3000 DR, Rotterdam, The Netherlands.
} 
METHOD

\section{Brain Material}

Human brain tissue was obtained via the rapid autopsy program of the Netherlands Brain Bank (coordinator, Dr. R. Ravid). Brain tissue for the present study was dissected from the superior frontal gyrus, superior occipital gyrus, the medial temporal gyrus and the hippocampus. The samples were taken from a group of eight controls (mean age: $68.2 \pm 15.3$ years), who had no history of neurological or psychiatric disorders, and of eight clinically diagnosed and neuropathologically confirmed Alzheimer's disease cases (mean age: $83.8 \pm 9.9$ years) (see Table 1 for details). Because the $\mathrm{pH}$ of the cerebrospinal fluids of both groups was identical (Table 1 ), no apperent differences in agonal state (38) between the two groups are present. Tissue was dissected fresh, frozen in liquid nitrogen and stored at $-80^{\circ} \mathrm{C}$.

The patients had been clinically assessed and the diagnosis of "probable AD" was assessed by first excluding other possible causes of dementia by history, physical examination, and laboratory tests. Clinical diagnoses of "probable AD" were based on the NINCIDS-ADRDA criteria (32). All cases were neuropathologically confirmed using conventional histopathological stainings including Bodian, H\&E, Congo red, and Alz-50. Diagnoses were based on the presence and distribution of plaques and tangles in the sections.

\section{Isolation and Preparation of DNA Samples}

RNase A, RNase T1, micrococcal endonuclease, spleen phosphodiesterase, and nuclease P1 were obtained from Boehringer
Mannheim (Almere, The Netherlands); proteinase $\mathrm{K}$ from Gibco BRL (Life Technologies Inc., Gaithersburg, MD). 8OHdG was kindly supplied by Dr. C. Richter, Zurich, Switzerland. Deoxynucleosides $2^{\prime}$-deoxyadenosine, $2^{\prime}$-deoxycytosine, 2'-deoxyinosine, $2^{\prime}$-deoxyguanosine (dG), and thymidine were obtained from Sigma, St. Louis, MO.

Approximately $50 \mathrm{mg}$ of brain tissue was powdered in liquid nitrogen and further homogenized using a Polytron homogenizer in digestion buffer $(10 \mathrm{mM}$ Tris- $\mathrm{HCl}, 5 \mathrm{mM}$ EDTA, $0.5 \% \mathrm{wt} / \mathrm{vol}$ sodium dodecyl sulphate; $\mathrm{pH} 7.8$ ). After incubation with proteinase $\mathrm{K}\left(500 \mu \mathrm{g} / \mathrm{ml}\right.$ for $3 \mathrm{~h}$ at $\left.38^{\circ} \mathrm{C}\right), 20 \% \mathrm{vol} / \mathrm{vol}$ potassium acetate $(8 \mathrm{M})$ was added and the solution was gently mixed for $5 \mathrm{~min}$. Subsequently, 1 volume of chloroform was added. After gentle mixing for $5 \mathrm{~min}$, the mixture was centrifuged at $2000 \times \mathrm{g}$ for 5 $\min$ at $4^{\circ} \mathrm{C}$. From the aqueous layer, DNA was precipitated by addition of $2 \mathrm{vol}$ of $100 \%$ ethanol (stored at $-20^{\circ} \mathrm{C}$ for $30 \mathrm{~min}$ or overnight). After centrifugation $\left(5 \mathrm{~min}, 800 \times \mathrm{g}, 4^{\circ} \mathrm{C}\right.$ ), the precipitate was washed with $70 \% \mathrm{vol} / \mathrm{vol}$ ethanol, and again centrifuged. After reconstitution of the pellet at $4^{\circ} \mathrm{C}$ in TE buffer $(10 \mathrm{mM}$ Tris-HCL, $0.1 \mathrm{mM}$ EDTA; $500 \mu \mathrm{l} / 50 \mathrm{mg}$ tissue), Tris- $\mathrm{HCl}$ (1M; $\mathrm{pH} 7.4)$ was added to a final concentration of $50 \mathrm{mM}(50 \mu \mathrm{l} / \mathrm{ml})$. Stock solutions of RNase A and T1 were preincubated at $37^{\circ} \mathrm{C}$ for 15 min. RNase treatment of DNA was performed at $37^{\circ} \mathrm{C}$ for 30 min at final concentrations of $200 \mu \mathrm{g}$ RNase $\mathrm{A} / \mathrm{ml}$ and $100 \mathrm{U}$ RNase $\mathrm{Tl} / \mathrm{ml}$. RNase-treated DNA was precipitated with $100 \%$ ethanol, washed with $70 \% \mathrm{vol} / \mathrm{vol}$ ethanol, and reconstituted in TE as described above.

The quality of the isolated DNA (before and after RNase treatment) was assessed spectrophotometrically (routinely, ratios of

TABLE 1

HUMAN BRAIN TISSUE USED

\begin{tabular}{|c|c|c|c|c|c|c|}
\hline Pat Nr. & Sex & $\begin{array}{c}\text { Age } \\
\text { (years) }\end{array}$ & $\begin{array}{c}\text { PMD } \\
\text { (h:min) }\end{array}$ & $\begin{array}{l}\text { BW } \\
(\mathrm{g})\end{array}$ & $\mathrm{pH}$ & Clinicopathological Data \\
\hline \multicolumn{7}{|c|}{ A) Control subjects } \\
\hline $91-118$ & $\mathrm{~m}$ & 59 & $6: 00$ & 1415 & nd & Lung carcinoma, neuraxis radiation, trombo-emboli, pneumonia \\
\hline $91-120$ & $\mathrm{f}$ & 73 & $4: 25$ & 975 & 5.8 & Myocardial infarction \\
\hline $91-123$ & $\mathrm{f}$ & 71 & $7: 25$ & 1135 & 7.2 & Myocardial infarction, decompensatio cordis \\
\hline $91-124$ & $\mathrm{~m}$ & 38 & $7: 00$ & 1600 & 5.9 & Endocarditis, sepsis, multiorgan failure, acute infections \\
\hline $91-125$ & $\mathrm{~m}$ & 61 & $5: 40$ & 1380 & 6.4 & Adenocarcinoma, abdominal bleeding following stomach resection \\
\hline $92-029$ & $\mathrm{~m}$ & 79 & $5: 10$ & 1129 & 7.2 & Decompensatio cordis, pneumonia \\
\hline $92-030$ & f & 78 & $6: 35$ & 1084 & 7.0 & Myocardial infarction, decompensatio cordis, pneumothorax \\
\hline $92-032$ & $\mathrm{~m}$ & 87 & $8: 00$ & 1262 & 7.1 & Pancreatic carcinoma, lung infarction, liver metastases \\
\hline Mean & & 68.2 & $6: 17$ & 1250 & 6.65 & \\
\hline SD & & $(15.3)$ & $(1: 12)$ & $(210)$ & $(0.6)$ & \\
\hline \multicolumn{7}{|c|}{ B) Alzheimer patients } \\
\hline $90-038$ & $\mathrm{f}$ & 84 & $2: 30$ & 1185 & 6.6 & AD, pneumonia, sepsis, dehydration \\
\hline $90-056$ & f & 86 & $3: 45$ & 1070 & 6.6 & $\mathrm{AD}$, bronchopneumonia \\
\hline $90-066$ & $\mathrm{~m}$ & 89 & $4: 55$ & 1488 & 6.2 & $\mathrm{AD}$ \\
\hline $90-069$ & f & 91 & $4: 10$ & 1008 & 6.5 & $\mathrm{AD}$ \\
\hline $90-078$ & $\mathbf{f}$ & 84 & $3: 35$ & 1389 & 6.8 & $\mathrm{AD}$, decompensatio cordis \\
\hline $92-019$ & $\mathrm{~m}$ & 60 & $4: 40$ & 1331 & 6.5 & Presenile AD \\
\hline $92-020$ & f & 89 & $2: 55$ & 1172 & 6.7 & $\mathrm{AD}$, dehydration, pneumonia \\
\hline $92-023$ & f & 80 & $4: 20$ & 1007 & 6.8 & $\mathrm{AD}$ \\
\hline Mean & & $83.8^{*}$ & $4: 00 *$ & 1150 & 6.58 & \\
\hline SD & & $(7.3)$ & $(0: 50)$ & $(200)$ & $(0.19)$ & \\
\hline
\end{tabular}

Abbreviations: Pat Nr, patient code; f, female; m, male; AD, Alzheimer's disease; PMD, postmortem delay; BW, brain weight; pH, pH of the cerebrospinal fluid; nd, not recorded.

* Significantly different from the control group $(p<0.05$; unpaired $t$-test). 
absorbance at $260 \mathrm{~nm} / 280 \mathrm{~nm}$ were between 1.8 and 2.0 ) and by ethidium bromide/agarose gelelectrophoresis ( $1 \mu \mathrm{g}$ of DNA applied) (44). Rough quantitation of the amounts of DNA needed for DNA hydrolysis was perforrned spectrophotometrically (1 absorption unit at $260 \mathrm{~nm}$ corresponds to $50 \mu \mathrm{g} \mathrm{DNA} / \mathrm{ml}$ ).

\section{DNA Hydrolysis}

DNA was digested to nucleosides by adapted procedures as described earlier $(22,45,46)$. RNase-treated DNA was dissolved in Tris $\mathrm{HCl}(5 \mathrm{mM}$; pH 7.4). To $42 \mu$ l of DNA solution (containing less than $30 \mu \mathrm{g}$ DNA), $21 \mu 1$ endonuclease/phosphodiesterase mix was added (consisting of $6 \mu \mathrm{g}$ micrococcal endonuclease $/ \mu \mathrm{l}, 2.67$ $\mu \mathrm{g}$ spleen phosphodiesterase $/ \mu \mathrm{l}$ in $60 \mathrm{mM}$ sodium succinate, $\mathrm{pH}$ 6.0 , with $30 \mathrm{mM} \mathrm{CaCl}_{2}$ ). After incubation for $4 \mathrm{~h}$ at $37^{\circ} \mathrm{C}, 12.4 \mu \mathrm{l}$ nuclease P1 solution was added (composed of $40 \% \mathrm{vol} / \mathrm{vol} 5 \mu \mathrm{g}$ nuclease $\mathrm{P} 1 / \mu \mathrm{l}$ and $60 \% \mathrm{vol} / \mathrm{vol} 0.3 \mathrm{mM} \mathrm{ZnCl}$ in $0.417 \mathrm{M}$ sodium acetate, $\mathrm{pH} 5.0$ ). After incutration at $37^{\circ} \mathrm{C}$ for $40 \mathrm{~min}$, the digestion was terminated by the addition of methanol $(7.5 \mu 1)$ and HPLC eluent ( $83 \mu \mathrm{l}$; see below), 50 - $\mu 1$ aliquots were directly injected into the HPLC system.

\section{High-Performance Liquid Chromatography}

The eluent $(90 \%$ vol/vol citrate buffer $(50 \mathrm{mM}$, pH 3.5; containing $15 \mu \mathrm{M}$ EDTA), and $10 \% \mathrm{vol} / \mathrm{vol}$ methanol) was delivered isocratically at $1.0 \mathrm{ml} / \mathrm{min}$ by a Gynkotek model 300 pump (Separations, Hendrik Ido Ambacht, The Netherlands) equipped with a membrane-type pulse dampener. Samples $(50 \mu 1)$ were injected on the reverse phase column (Supelcosil LC-18-S; 250x4.6 mm, 5 $\mu \mathrm{m}$; Supelco, Leusden, The Netherlands) by a WISP-autosampler (Model 710B; Waters-Millipore, Bedford, MA). To quantitate normal DNA nucleosides (by UV) and $80 \mathrm{OHG}$ (by ECD), column effluent was passed through an UV detector set at $254 \mathrm{~nm}$ (Waters, model 490; Bedford, MA) followed by an electrochemical detector (Model CU-04-AZ; Antec Leyden, Leiden, The Netherlands; potential of the glassy carbon working electrode: $700 \mathrm{mV}$ vs. Ag/ $\mathrm{AgCl}$ reference electrode). From the UV trace, amounts of 2'deoxyguanosine $(\mathrm{dG})$ were quantitated. The capillary between the UV detector and the electrochemical detector was insulated with cotton wool to reduce base line noise of the electrochemical detector. Reproducibility of the overall assay was validated with human and rat brain: multiple DNA isolations were performed with the same tissue powdered in liquid nitrogen, followed by hydrolysis and HPLC analysis.

\section{Influence of Postmortem Delay and Storage Time on Levels of $8 O H d G$ in Rat Brain}

To study the possible influence of postmortem delay (PMD) on $80 H d G$ levels, brain tissue of 17 male Brown-Norway/Billingham Rijswijk (BN/BiRij) rats (age 104-126 weeks, from the inbred strain of the Gaubius Lahoratory, TNO Prevention and Health) were processed after different PMDs. After cervical dislocation under mild halothane anesthesia, one hemisphere of each animal was processed after 30 min of PMD. The other hemisphere was processed at PMDs ranging from 5 to $420 \mathrm{~min}$.

Effects of freezing and thawing of tissue samples on $80 \mathrm{HdG}$ levels were studied with brain tissue of male BN/BiRij rats (75 weeks of age). The entire brain was homogenized in liquid nitrogen. The ratio $8 \mathrm{OHdG} / 10^{5} \mathrm{dG}$ in the tissue powder was determined directly, and after storage at $-70^{\circ} \mathrm{C}$ for $1 \mathrm{~h}$ followed by thawing, and again after a second time of freezing and thawing. Influences of storage time on $8 \mathrm{OHdG}$ levels in brain tissue (1 month at $\left.-70^{\circ} \mathrm{C}\right)$ or isolated DNA $\left(1\right.$ month at $\left.4^{\circ} \mathrm{C}\right)$ were investigated in triplicate using rat brain tissue of male BN/BiRij rats ( 75 weeks of age).

\section{Data Presentation and Analysis}

Amounts of $\mathrm{dG}$ and $8 \mathrm{OHdG}$ were quantified based on peak area measurements of the UV- and ECD-chromatograms, using the Peakmaster 3 chromatography data system (Harley Systems Ltd., Bucks, United Kingdom). The UV signals of DNA nucleosides were calibrated with dG standards. Because the $\mathrm{dG}$ standard contained small amounts of $80 \mathrm{OHG}$, calibrations of $80 \mathrm{HdG}$ were performed in separate runs with purified $80 \mathrm{HdG}$. Oxidative damage to DNA was expressed as the ratio $80 \mathrm{OHdG} / 10^{5} \mathrm{dG}$.

Results are presented as mean \pm SD. Statistically significant correlations were evaluated using multiple regression analysis (12).

\section{RESULTS}

\section{DNA Isolation and Hydrolysis}

For the determination of $8 \mathrm{OHdG}$ levels in human brain, DNA had to be isolated from relatively small frozen samples. The method devised in the present study allowed isolation of DNA from autopsy specimens of approximately $50 \mathrm{mg}$. Routinely, between 25 and $50 \mu \mathrm{g}$ of DNA was obtained, enough to complete the entire assay. Ethidium bromide/agarose gelelectrophoresis showed that the DNA was of high molecular weight, not degraded, and contained no detectable amounts of RNA.

HPLC analysis of enzymatically hydrolyzed DNA showed that the DNA was completely digested to deoxynucleosides after incubation in the micrococcal endonuclease/spleen phosphodiesterase mixture, followed by treatment with nuclease P1 (Fig. 1B).

\section{HPLC Chromatography}

Deoxynucleosides were well separated on the reverse phase column and could be conveniently detected at $254 \mathrm{~nm}$. 2' Deoxyinosine, a degradation product of $2^{\prime}$-deoxyadenosine, was present in all digested DNA samples (Fig. 1). By passing the effluent of the UV detector through the electrochemical detector, amounts of $\mathrm{dG}$ and $80 \mathrm{OHdG}$ were quantified within the same run (Fig. 1A and B). The identity of $80 \mathrm{OHdG}$ in hydrolyzed DNA was established by its retention time (identical to that of purified $80 \mathrm{HdG}$; Fig. 2), cochromatography of hydrolyzed DNA with purified $8 \mathrm{OHdG}$, and by the fact that voltammograms of the purified $80 \mathrm{HdG}$ standard and the putative $80 \mathrm{HdG}$ peak in hydrolyzed DNA were identical $(E \approx 750 \mathrm{mV}$; data not shown). With this analytical system, the detection limit of $80 \mathrm{HdG}$ was $3 \mathrm{fmol}$ per injection. Routinely, determination of $8 \mathrm{OHdG}$ levels in hydrolyzed DNA involved 50-200 fmol $80 \mathrm{OdG}$ and 2-5 nmol dG per injection. Ratios $8 \mathrm{OHdG} / 10^{5} \mathrm{dG}$ as low as 0.5 could be determined reliably.

Calibration curves were linear from $20-600 \mathrm{fmol} 80 \mathrm{HdG}$ and $0.5-5 \mathrm{nmol} \mathrm{dG}$, with correlation coefficients $>0.999$. Variation in the sensitivity of the HPLC assay with time was negligible: over a period of $24 \mathrm{~h}$, repeated injections of the same sample resulted in variations in $8 \mathrm{OHdG} / 10^{5} \mathrm{dG}$ ratio of less than $5 \%$. Reproducibility of the overall assay (DNA isolation, hydrolysis and HPLC analysis) was satisfactory: the complete procedure resulted in a coefficient of variation of $7.2 \%(n=15) .80 H d G$ levels were not affected by the enzymatic hydrolysis procedure: when purified $80 H d G$ was subjected to the enzymatic digestion procedure (incubation with endonuclease and phosphodiesterase, followed by nuclease P1) amounts of $8 \mathrm{OHdG}$ determined by HPLC-ECD re- 


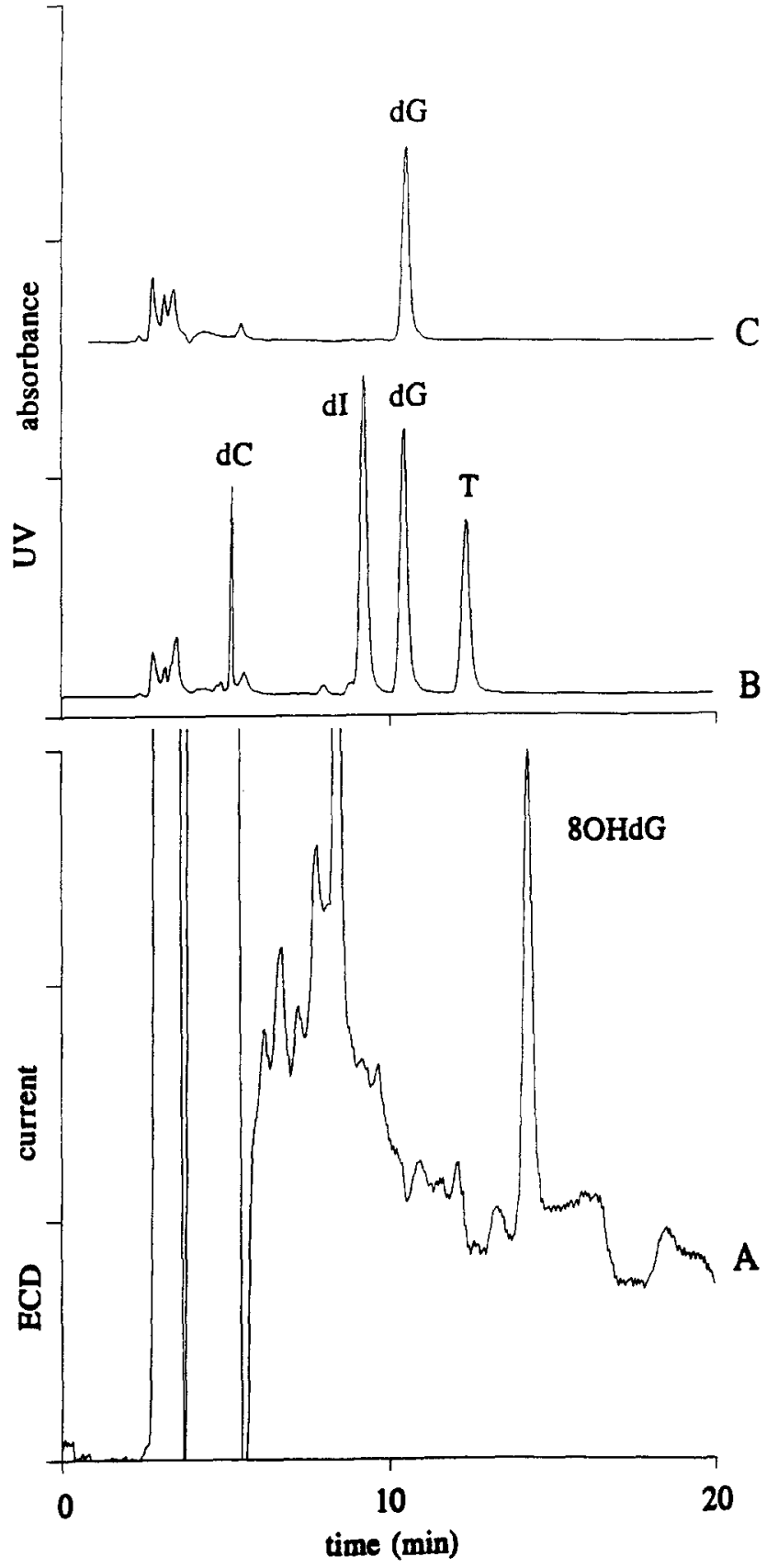

FIG. 1. HPLC chromatograms of hydrolyzed DNA, isolated from human brain tissue (control subject 91-118, frontal cortex): simultaneous UV and electrochemical detection (see the Methods section for details). Column effluent was monitored by UV-detection (trace B; $254 \mathrm{~nm}$; representing $2581 \mathrm{pmol} d G$ ) followed by electrochemical detection $(\mathrm{ECD}$; trace $\mathrm{A}$; representing $141 \mathrm{fmol} 8 \mathrm{OHdG})$. Trace $\mathrm{C}$; deoxyguanosine, $2000 \mathrm{pmol}$ injected. dC, 2'-deoxycytosine; ECD, electrochemical detection; dG, 2'deoxyguanosine; dI, $2^{\prime}$-deoxyinosine; $80 \mathrm{HdG}, 8$-hydroxy-2'-deoxyguanosine; T, thymidine; $\mathrm{UV}$, ultraviolet detection at $254 \mathrm{~nm}$.

mained unchanged. Furthermore, levels of $8 \mathrm{OHdG} / 10^{5} \mathrm{dG}$ were independent of the amount of frozen tissue used for DNA isolation (ranging from $50 \mathrm{mg}$ to $1 \mathrm{~g}$ ), and independent of the amounts of DNA subjected to enzymatic hydrolysis and HPLC analysis (ranging from 10 to $40 \mu \mathrm{g}$ of DNA).

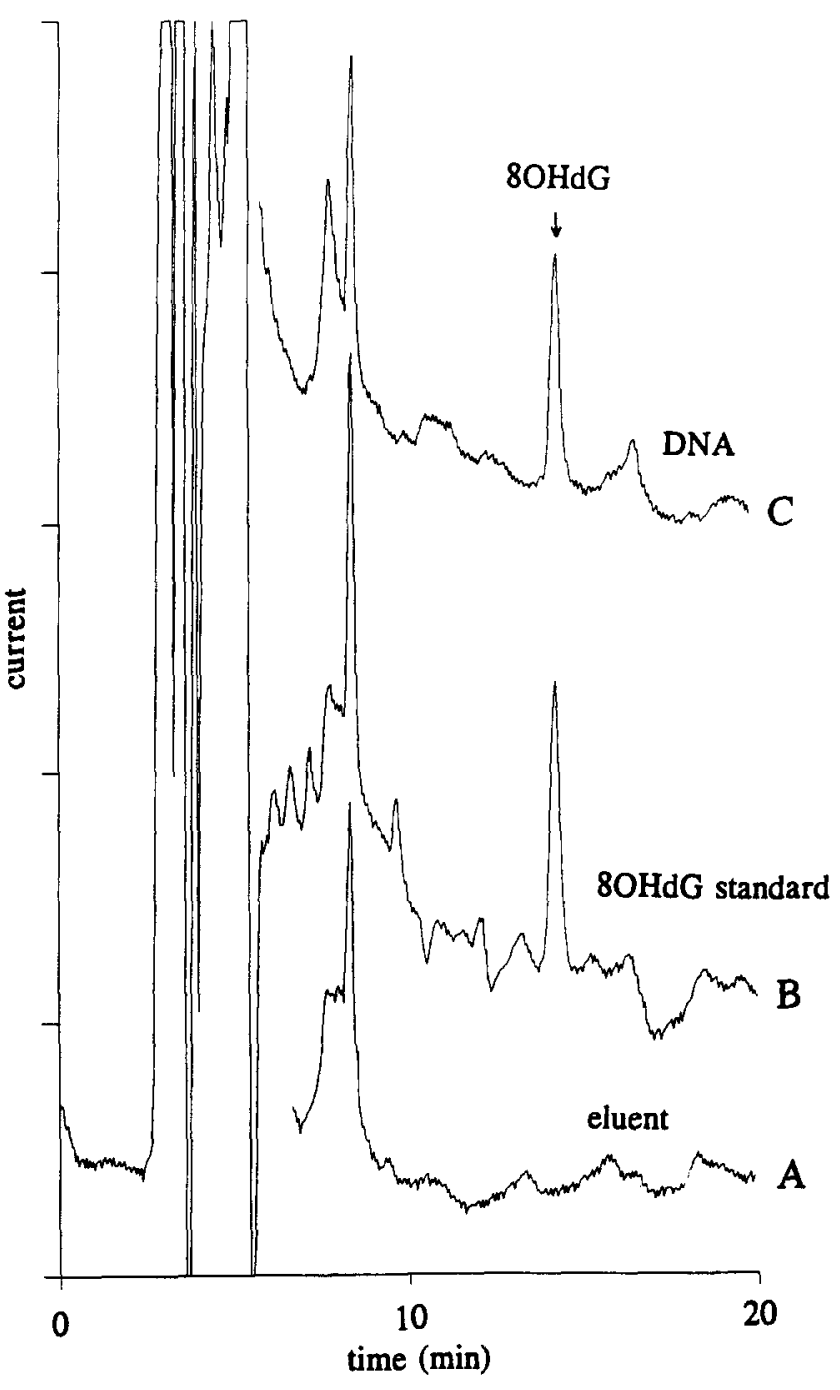

FIG. 2. HPLC chromatograms with electrochemical detection. Trace A, blank eluent; Trace B, $80 \mathrm{HdG}$ standard (50 fmol injected); Trace C, hydrolyzed DNA (AD subject 92-023, frontal cortex; corresponding to a $8 \mathrm{OHdG} / 10^{5} \mathrm{dG}$ ratio of 2.25 ).

\section{Effect of Storage and Postmortem Delay on $80 \mathrm{HdG} / 10^{5} d G$ Ratios in Rat Brain}

$8 \mathrm{OHdG} / 10^{5} \mathrm{dG}$ ratios in directly processed frozen rat brain did not differ significantly from values obtained in brain specimens that had been thawed and frozen again once $(p>0.2$, triplicate assays). In addition, thawing for a second time did not affect $80 \mathrm{HdG}$ levels ( $p>0.5$, triplicate assays). Similarly, storage of rat brain $\left(-70^{\circ} \mathrm{C}, 1\right.$ month) or isolated DNA $\left(1\right.$ month at $\left.4^{\circ} \mathrm{C}\right)$ did not influence $80 \mathrm{HdG}$ levels $(p>0.5$ and $p>0.1$, resp.; triplicate assays).

Possible postmortem delay (PMD) influences on $80 \mathrm{HdG}$ levels in brain tissue were investigated in rats with PMDs ranging from $5 \mathrm{~min}$ to $7 \mathrm{~h}$. No statistically significant relationship of $8 \mathrm{OHdG}$ levels with PMD was observed (Fig. $3 ; p>0.4$ ).

\section{OHdG Levels in Postmortem Human Brain}

In frontal, occipital, and temporal cortex tissue and tissue from the hippocampus, 1-7 molecules $80 \mathrm{HdG}$ per $10^{5} \mathrm{dG}$ were mea- 


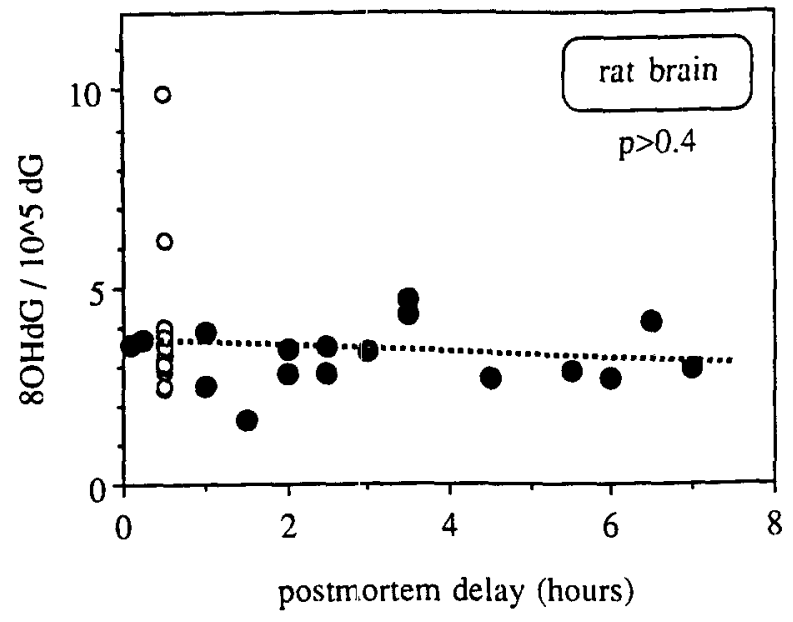

FIG. 3. Influence of postmortem delay on $80 \mathrm{HdG}$ levels in rat brain. One hemisphere of each rat was processed after a postmortem delay of $30 \mathrm{~min}$ (open circles). The other hemisphere was processed with a postmortem delay between $5 \mathrm{~min}$ and $7 \mathrm{~h}$ (closed circles).

sured. On average, about 2 oxidized dG molecules were encountered per $10^{5} \mathrm{dG}$. No age-related increases in oxidative DNA damage were observed in human brain of control subjects $(p>0.6$; Fig. 4A; compilation of all analyzed brain areas. After omission of the high value $>580 H d G$ per $10^{5} \mathrm{dG}$, of subject $91-118$, age 59 , or 91-124, age 38: $p>0.3)$ or AD patients $(p>0.6$; Fig. $4 \mathrm{~B}$; pooled data of all brain areas). In human brain, similar to rat brain, no relationship between 8OHdG levels and PMD (ranging from $2 \mathrm{~h}$
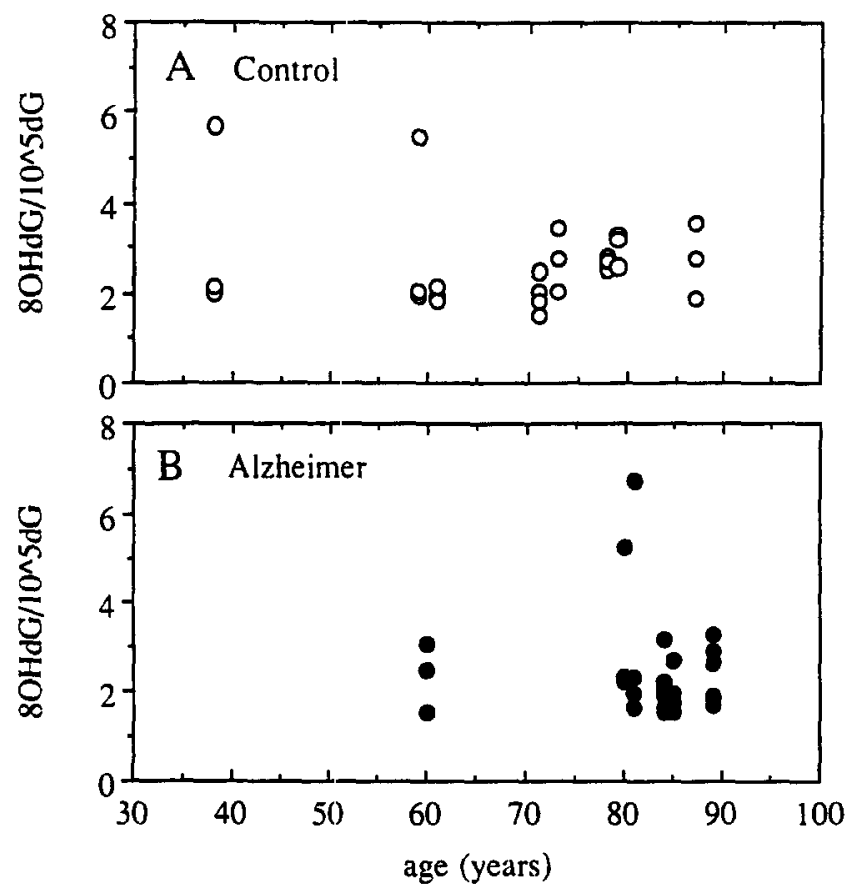

FIG. 4. Oxidative DNA damage $\left(8 \mathrm{OHdG} / 10^{5} \mathrm{dG}\right)$ in human brain as a function of age in control suljects (A) and Alzheimer patients (B). Data of all brain areas studied.
$55 \mathrm{~min}$ to $8 \mathrm{~h}$ ) was observed (Fig. 5; frontal cortex, $p>0.2$; temporal cortex, $p>0.05$; hippocampus, $p>0.4 ; p$-values were obtained with combined data of AD and control subjects).

Levels of oxidative DNA damage were identical in different areas of the brain. No regional differences were found between frontal cortex, temporal cortex, occipital cortex, and hippocampus in control individuals $(p>0.9$; Fig. $6 \mathrm{~A})$, nor in $\mathrm{AD}$ patients $(p>$ 0.8 ; Fig. 6B). Levels of $8 \mathrm{OHdG}$ were not correlated with sex in either control individuals or $\mathrm{AD}$ patients $(p>0.7$ and $p>0.3$, respectively). Most importantly, no differences in this type of oxidative DNA damage were observed between control subjects and AD patients ( $p>0.5$; Fig. 7 ; compiled data of all brain areas measured). Furthermore, $8 \mathrm{OHdG}$ levels in specific areas of the brain (hippocampus, frontal, occipital, and temporal cortex) showed no differences between $\mathrm{AD}$ patients and control subjects $(p>0.1)$. Thus, the amount of 8OHdG was comparable in all areas investigated, with no differences present between $A D$ patients and control subjects.

To substantiate that the observed levels of $80 \mathrm{OHdG}$ do not reflect artifacts due to experimental procedures, levels of the adduct in human brain (all subjects included in this study) were compared to 80HdG levels in DNA isolated from WAG/Rij rats (age 53-81 weeks). The extent of oxidative DNA damage was found to be significantly higher in human brain as compared to rat brain (average levels of $8 \mathrm{OHdG} / 10^{5} \mathrm{dG} \pm \mathrm{SD}$ : human brain, $2.5 \pm 1.1, n=$ 55; rat brain, $0.55 \pm 0.10, n=11 ; p<0.001)$. Furthermore, a 95 -fold increase in $80 \mathrm{HdG}$ levels was observed when DNA was subjected to oxidative modification by vitamin $\mathrm{C}$ plus $\mathrm{CuSO} 4$ according to others $(27,39)$.

\section{DISCUSSION}

In the present study, existing HPLC methods were adapted to determine $80 \mathrm{OHG}$ levels in small human postmortem brain samples. High molecular weight DNA, free of RNA, was obtained from small autopsy specimens of about $50 \mathrm{mg}$. By means of HPLC, amounts of dG as well as $8 \mathrm{OHdG}$ could be quantified reproducibly and sensitively within the same run with a detection limit for $8 \mathrm{OHdG}$ as low as $3 \mathrm{fmol}$ per injection. Furthermore, our parametric studies show that no relationship is present between $8 \mathrm{OHdG}$ levels and potentially disturbing factors such as postmortem delay, repeated freezing and thawing of brain tissue, or storage of the tissue. Effects of other factors that may result in oxidative

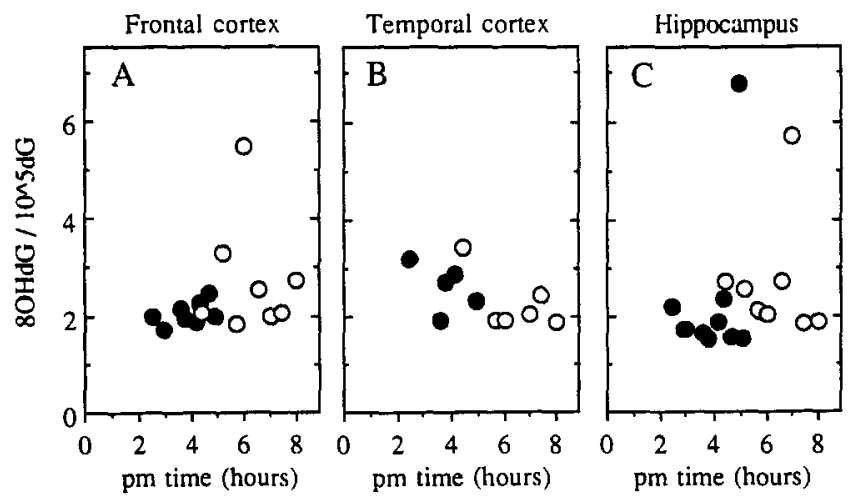

FIG. 5. Influence of postmortem delay on 8OHdG levels in human brain. Levels of oxidative DNA damage in human brain autopsy samples were plotted against the postmortem delay. (A) Frontal cortex; (B) temporal cortex; (C) hippocampus. Closed circles, AD patients; open circles, control individuals. 


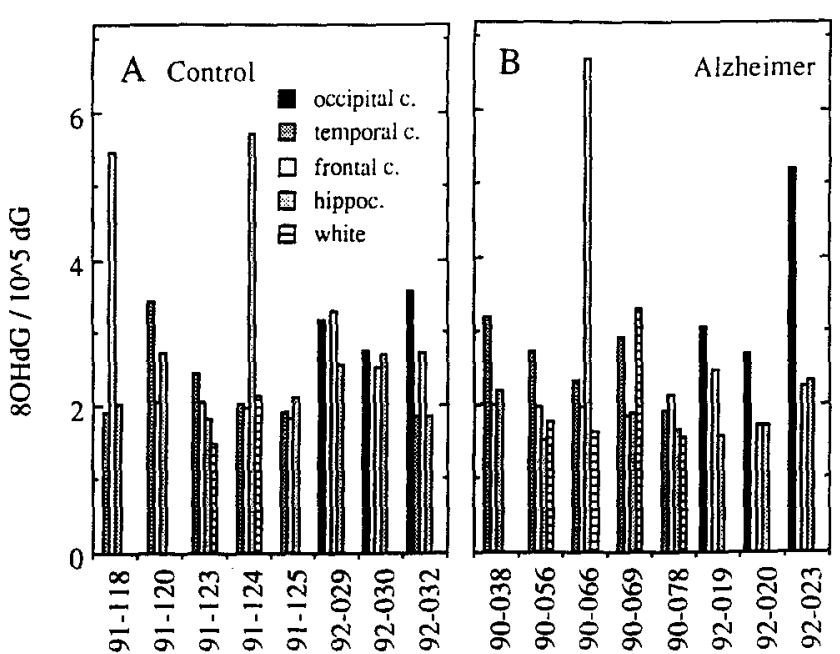

FIG. 6. $80 \mathrm{HdG}$ levels in different areas of human brain of control subjects (A) and Alzheimer patients (B). Numbers indicate subject codes (see Table 1); c, cortex; hippoc., hippocampus; white, white matter. Absent bars: not determined.

stress at the time of death, such as transient brain ischemia are unknown as yet and merit further research.

As a final outcome, $80 \mathrm{HdG}$ levels in human brain did not differ between the areas studied, nor were differences found between control subjects and AD patients. Approximately 2 oxidized dG molecules were present per $10^{5} \mathrm{dG}$, irrespective of the presence or

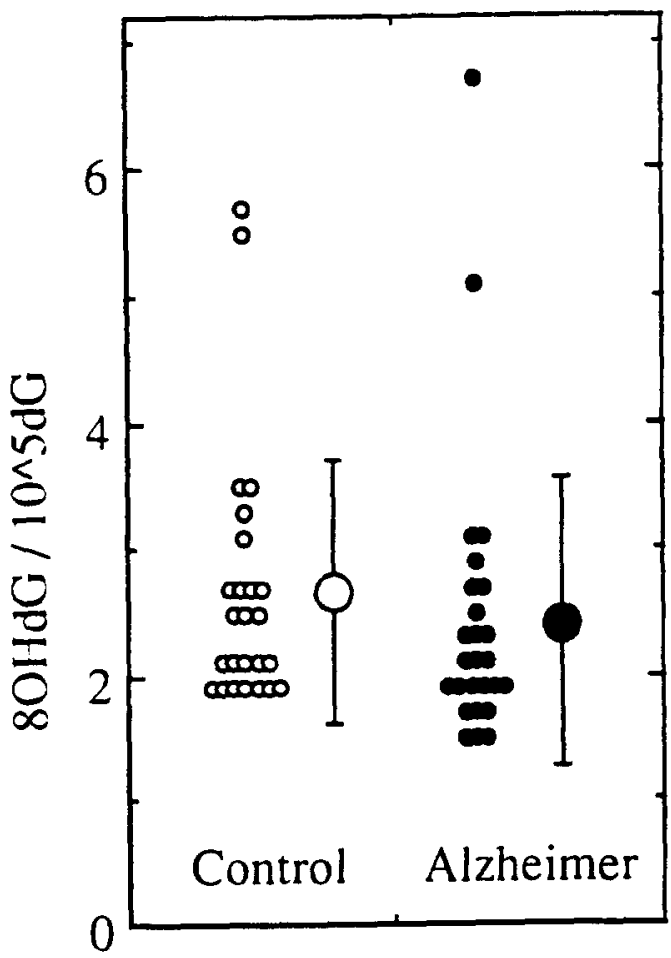

FIG. 7. Compiled data of oxidative DNA damage $\left(8 \mathrm{OHdG} / 10^{5} \mathrm{dG}\right)$ in specimens of different brain areas (frontal, occipital and temporal cortex and hippocampus) of control subjects ( 25 tissue samples) and of Alzheimer patients (27 tissue samples). Comparison of control subjects and AD patients: $p>0.5$. absence of $\mathrm{AD}$, or brain area studied. The range of $8 \mathrm{OHdG}$ levels (i.e., $1-7 / 10^{5} \mathrm{dG}$ ) is in good agreement with values reported in literature $(22,33,34)$. In general, our data indicate that $8 \mathrm{OHdG}$ is present in the brain in fairly high levels without a preferential localization. These high basal levels of $8 \mathrm{OHdG}$ are in agreement with the work of others $(16,33,34,39)$. Levels of 8 OHdG have been reported to increase with age in rat liver, kidney, and intestine, but not in rat brain and testes (16), nor in human leucocytes (51). Similarly, we did not find an age-related increase in $80 \mathrm{OHG}$ in human brain tissue ( $p>0.4 ; n=55$, pooled data of control subjects, Fig. 4A, and Alzheimer patients, Fig. 4B). At first sight, our data seem to deviate form those reported by Mecocci et al. $(33,34)$ : they showed a weak correlation of $80 \mathrm{OHG}$ levels in nuclear DNA of control subjects with age $(r=0.47, p=0.03$; all analyzed samples taken together). In particular, two subjects aged over 90 years contributed to this conclusion. Furthermore, $8 \mathrm{OHdG}$ levels were only correlated with age in cerebellum, and not in frontal, parietal or temporal cortex (34). Our data of control subjects, covering age $38-87$ without individuals with age $>90$ (Fig. 4A), are consistent with those of Mecocci et al. (34). However, statistical analysis of our data does not allow the conclusion that levels of $80 \mathrm{HdG}$ in nuclear DNA increase with age $(p>0.6)$.

Furthermore, our data do not support differences in $8 \mathrm{OHdG}$ levels in nuclear DNA between $\mathrm{AD}$ patients and control subjects, in contrast to Mecocci et al. (33). Here again, both data sets are virtually identical, but lead to different conclusions. In both studies, $80 \mathrm{HdG}$ levels in specific brain areas are identical between $\mathrm{AD}$ and control. Furthermore, in both studies, $80 \mathrm{HdG}$ levels in $\mathrm{AD}$ and control are identical when all tissues analyzed are combined, and when expressing oxidative damage as the $8 \mathrm{OHdG} / 10^{5} \mathrm{dG}$ ratio. Surprisingly, a significant difference between $A D$ and control was only observed if oxidative DNA damage of the pooled data was expressed as fmol $80 \mathrm{HdG} / \mu \mathrm{g}$ DNA (33). Our study was restricted to oxidative DNA damage expressed as the ratio $8 \mathrm{OHdG} / 10^{5} \mathrm{dG}$. Altogether, both data sets are essentially not different, but lead to different conclusions.

The hypothesis that oxidative DNA damage is involved in the etiology of $\mathrm{AD}$ suggests that increased levels of $8 \mathrm{OHdG}$ should be most easily detected in temporal cortex and hippocampus, the brain areas most affected by AD. However, our data (Fig. 5B) and those of Mecocci et al. (33) show that differences between $A D$ and control are lacking in temporal cortex. Similarly, levels of $8 \mathrm{OHdG}$ in hippocampus were not different between $A D$ and control (Fig. 5C). Thus, comparison of oxidative DNA damage in different areas of the brain does not support a role of oxidative DNA damage in the etiology of AD.

A shortcoming of the present data set is the difference in PMD and age of AD patients and control subjects (Table 1). However, both factors do not confound our conclusions for 1) PMD (4:00 \pm $0.50 \mathrm{~h}$ in $\mathrm{AD} ; 6: 17 \pm 1.12 \mathrm{~h}$ in control) showed no relationship with $80 \mathrm{OHdG}$ levels (Fig. 5); and 2) the rat study designed to evaluate the effect of PMD on $8 \mathrm{OHdG}$ levels also does not support a relationship between PMD and 80 HdG levels (Fig. 3). Similarly, the shortcoming that age of control $(68.2 \pm 15.3)$ and $\mathrm{AD}(83.8 \pm$ 7.3) groups are different does not confound our conclusion since 1) we show that $80 \mathrm{HdG}$ levels in nuclear DNA do not increase with age; and 2) if age-related accumulation of $80 H d G$ was to occur (34), our significantly older AD group would have had higher $80 \mathrm{HdG}$ levels than the younger control group. However, this is not what we found: $80 \mathrm{HdG}$ levels in $\mathrm{AD}$ and control subjects did not differ from each other.

Whereas the present study, altogether, does not support a role for oxidative $\mathrm{DNA}$ damage in the etiology of $\mathrm{AD}$, it does not take into account local differences in nuclear $80 \mathrm{OHdG}$ levels between particular brain areas (on a microscopic level), or between particu- 
lar cell types (e.g., glia vs. neurons), or loss of oxidative DNA damage due to cell death. Such effects cannot be detected with the present HPLC method where brain homogenates have been used. Investigations to address these issues require a (immuno)histological approach that is presenily not available.

In addition, besides damage to nuclear DNA, mitochondrial DNA which accounts for about $1 \%$ of the total cellular DNA has been suggested as a target for oxidative damage $(3,8,30,37,48,53)$. $80 H d G$ levels in mitochondrial DNA have been shown to be tenfold higher than those in nuclear DNA and show prominent increases in both normal aging and $\operatorname{AD}(33,34,39)$. It is clear that on the basis of $80 \mathrm{HdG}$ levels, mitochondrial DNA is much more affected than nuclear DNA in both conditions $(33,34)$. Whether increased levels of $8 \mathrm{OHdG}$ in mitochondrial DNA play a causal role in $\mathrm{AD}$ etiology or are merely a consequence of the disease, merits further investigations.

We conclude that previous studies $(33,34)$ as well as the present data demonstrate relatively high basal levels of $8 \mathrm{OHdG}$ throughout life, without a preferential anatomical localization. As far as damage to nuclear DNA in brain is concerned, our present findings on 8OHDG do not demonstrate an accumulation of this particular oxidative DNA adduct with age. Other types of oxidative DNA damage, however, may be involved in AD etiology.

\section{ACKNOWLEDGEMENTS}

We express our gratitude to the Netherlands Brain Bank (Coordinator Dr. R. Ravid) for provision of well characterized human brain material, Prof. Dr. F.C. Stam (Netherlands Brain Bank), Dr. W. Kamphorst (Free University, Amsterdam), Dr. D. Troost (Academical Medical Centre, Amsterdam) for the neuropathological evaluation of the tissues, the Ministry of Health, Welfare and Sports of The Netherlands and the Netherlands Organization for Scientific Research (NWO; Grant 900-552-083 to P.J.L.) for financial support and Dr. C. Richter (Dept. Biochemistry, Swiss Federal Institute of Technology, Zürich, Switzerland) who kindly supplied purified $8 \mathrm{OHdG}$.

\section{REFERENCES}

1. Ames, B. N.; Shigenaga, M. K. Oxidants are a major contributor to aging. Ann. NY Acad. Sci. 663:85-96; 1992.

2. Aruoma, O. I.; Halliwell, B.; Gajewski, E.; Dizdaroglu, M. Copperion-dependent damage to the bases in DNA in the presence of hydrogen peroxide. Biochem. J. 273:601-604; 1991.

3. Beal, M. F.; Hyman, B. T.; Koroshetz, W. Do defects in mitochondrial energy metabolism underlie the pathology of neurodegenerative diseases? Trends Neurosci. 16:125-131; 1993.

4. Boerrigter, M. E.; Wei, II. Y.; Vijg, J. DNA repair and Alzheimer's disease. J. Gerontol. 47:E177-B184; 1992.

5. Bradley, W. G.; Robison, S. H.; Tandan, R. Deficient repair of alkylation damage of DNA in Alzheimer's disease and amyotrophic lateral sclerosis cells. Adv. Exp. Med. Biol. 209:3-6; 1987.

6. Cheng, K. C.; Cahil, D. S.; Kasai, H.; Nishimura, S.; Loeb, L. A. 8-Hydroxyguanine, an abundant form of oxidative DNA damage causes $\mathrm{G} \rightarrow$ $T$ and $A \rightarrow C$ substitution.s. J. Biol. Chem. 267:166-172; 1992.

7. Connor, J. R.; Snyder, B. S.; Beard, J. L.; Fine, R. E.; Mufson, E. J. Regional distribution of iron and iron-regulatory proteins in the brain in aging and Alzheimer's disease. J. Neurosci. Res. 31:327-335; 1992.

8. Corral-Debrinski, M.; Horton, T.; Lott, M. T.; Shoffner, J. M.; McKee, A. C.; Beal, M. F.; Grahıım, B. H.; Wallace, D. C. Marked changes in mitochondrial DNA deletion levels in Alzheimer brains. Genomics 23:471-476; 1994

9. Davies, K. J. Protein damage and degradation by oxygen radicals. I. General aspects. J. Biol. Chem. 262:9895-9901; 1987.

10. Dedman, D. J.; Treffy, A.; Candy, J. M.; Taylor, G. A. A.; Morris, C. M.; Bloxham, C. A.; Perry, R. H.; Edwardson, J. A.; Harrison, P. M. Iron and aluminium in relation to brain ferritin in normal individuals and Alzheimer's disease and chronic renal dialysis patients. Biochem. J. 287:509-514; 1992.

11. Dizdaroglu, M.; Rao, G.; Halliwell, B.; Gajewski, E. Damage to the DNA bases in mammalian chromatin by hydrogen peroxide in the presence of ferric and cupric ions. Arch. Biochem. Biophys. 285:317324; 1991

12. Edwards, A. A. L. Multiple regression and the analysis of variance and covariance. New York: Freeman; 1985

13. Fernandes, M. A. S.; Santana, I.; Januario, C.; Cunha, L.; Oliveira, C. R. Decreased superoxide dismutase activity in erythrocytes from patients with Alzheimer's disease. Med. Sci. Res. 21:679-682; 1993.

14. Floyd, R. A. Oxygen ratical-mediated damage to brain tissue. Basic Life Sci. 49:1015-1023; 1988.

15. Floyd, R. A.; Carney, J. M. Free radical damage to protein and DNA: Mechanisms involved and relevant observations on brain undergoing oxidative stress. Ann. Neurol. Suppl. 32:\$22-S27; 1992.

16. Fraga, C. G.; Shigenaga, M. K.; Park, J. W.; Degan, P.; Ames, B. N. Oxidative damage to DINA during aging: 8-Hydroxy-2'-deoxyguanosine in rat organ DNA and urine. Proc. Natl. Acad. Sci. USA 87:4533$4537 ; 1990$.
17. Friedlich, A. L.; Butcher, L. L. Involvement of free oxygen radicals in beta-amyloidosis: An hypothesis. Neurobiol. Aging 15:443-455; 1994.

18. Gaubatz, J. W.; Tan, B. H. Aging affects the levels of DNA damage in postmitotic cells. Ann. NY Acad. Sci. 719:97-107; 1994.

19. Gerlach, M.; Ben-Shachar, D.; Riederer, P.; Youdim, M. B. H. Altered brain metabolism of iron as a cause of neurodegenerative disease? J. Neurochem. 63:793-807; 1994.

20. Halliwell, B. Oxygen radicals as key mediators in neurological disease: Fact or fiction? Ann. Neurol. Suppl. 32:S10-S15; 1992.

21. Halliwell, B. Free radicals, antioxidants, and human disease: Curiosity, cause, or consequence? Lancet 344:721-724; 1994.

22. Halliwell, B.; Dizdaroglu, M. The measurement of oxidative damage to DNA by HPLC and GC/MS techniques. Free Radic. Res. Commun. $16: 75-87 ; 1992$.

23. Halliwell, B.; Gutteridge, J. M. Oxygen free radicals and iron in relation to biology and medicine: Some problems and concepts. Arch Biochem. Biophys. 246:501-514; 1986.

24. Hayakawa, M.; Torii, K.; Sugiyama, S.; Tanaka, M.; Ozawa, T. Ageassociated accumulation of 8-hydroxydeoxyguanosine in mitochondrial DNA of human diaphragm. Biochem. Biophys. Res. Commun. 179:1023-1029; 1991.

25. Holmes, G. E.; Bernstein, C.; Bernstein, H. Oxidative and other DNA damages as the basis of aging: A review. Mutat. Res. 275:305-315; 1992.

26. Kasai, H.; Crain, P. F.; Kuchino, Y.; Nishimura, S.; Ootsuyama, A. Tanooka, H. Formation of 8-hydroxyguanine moiety in cellular DNA by agents producing oxygen radicals and evidence for its repair. Carcinogenesis 7:1849-1851; 1986

27. Kasai, H.; Nishimura, S. Hydroxylation of deoxyguanosine at the C-8 position by ascorbic acid and other reducing agents. Nucleic Acids Res. 12:2137-2145; 1984.

28. Leadon, S. A: Cooper, P. K. Preferential repair of ionizing radiationinduced damage in the transcribed strand of an active human gene is defective in Cockayne syndrome. Proc. Natl. Acad. Sci. USA 90: 10499-10503; 1993.

29. Lewis, P. N.; Lukiw, W. J.; De Boni, U.; Crapper McLachlan, D. R. Changes in chromatin structure associated with Alzheimer's disease. J. Neurochem. 37:1193-1202; 1981.

30. Linnane, A. W.; Marzuki, S.; Ozawa, T.; Tanaka, M. Mitochondrial DNA mutations as an important contributor to ageing and degenerative diseases. Lancet 1(8639):642-645; 1989.

31. Loft, S.; Vistisen, K.; Ewertz, M.; Tjonneland, A.; Overvad, K.; Poulsen, H. E. Oxidative DNA damage estimated by 8 -hydroxydeoxyguanosine excretion in humans: Influence of smoking, gender and body mass index. Carcinogenesis 13:2241-2247; 1992.

32. McKhann, G.; Drachman, D.; Folstein, M.; Katzman, R.; Price, D.; Stadlan, E. M. Clinical diagnosis of Alzheimer's disease: Report of the NINCDS-ADRDA Work Group under the auspices of Department of 
Health and Human Services Task Force on Alzheimer's Disease. Neurology 34:939-944; 1984.

33. Mecocci, P.; MacGarvey, U.; Beal, M. F. Oxidative damage to mitochondrial DNA is increased in Alzheimer's disease. Ann. Neurol. 36: 747-751; 1994

34. Mecocci, P.; MacGarvey, U.; Kaufman, A. E.; Koontz, D.; Shoffner, J. M.; Wallace, D. C.; Beal, M. F. Oxidative damage to mitochondrial DNA shows marked age-dependent increases in human brain. Ann. Neurol. 34:609-616; 1993.

35. Mello-Filho, A. C.; Meneghini, R. Iron is the intracellular metal involved in the production of DNA damage by oxygen radicals. Mutat. Res. 251:109-113; 1991 .

36. Mullaart, E.; Boerrigter, M. E.; Ravid, R.; Swaab, D. F.; Vijg, J. Increased levels of DNA breaks in cerebral cortex of Alzheimer's disease patients. Neurobiol. Aging 11:169-173; 1990.

37. Nagley, P.; MacKay, I. R.; Baumer, A.; Maxwell, R. J.; Vaillant, F.; Wang, Z.-X.; Linnane, A. W. Mitochondrial DNA mutation associated with aging and degenerative disease. Ann. NY Acad. Sci. 673:92-102; 1992.

38. Ravid, R.; Van Zwieten, E. J.; Swaab, D. F. Brain banking and the human hypothalamus-Factors to match for, pitfalls and potentials. In: Swaab, D. F.; Hofman, M. A.; Mirmiran, M.; Ravid, R.; van Leeuwen, F. W., eds. Progress in brain research, vol. 93, Amsterdam: Elsevier; 1992:83-95.

39. Richter, C.; Park, J. W.; Ames, B. N. Normal oxidative damage to mitochondrial and nuclear DNA is extensive. Proc. Natl. Acad. Sci. USA 85:6465-6467; 1988.

40. Robbins, J. H; Otsuka, F; Tarone, R. E.; Polinsky, R. J.; Brumbach, R. A.; Moshell, A. N.; Nee, L.; Ganges, M. B.; Cayeux, S. J. Radiosensitivity in Alzheimer's disease and Parkinson's disease. Lancet 1(8322):468-469; 1983.

41. Robison, S. H.; Bradley, W. G. DNA damage an' chronic neuronal degenerations. J. Neurol. Sci. 64:11-20; 1984.

42. Robison, S. H.; Bradley, W. G. Impaired DNA repair replication in Alzheimer's disease cells. In: Hutton, J. T.; Kenney, A. D., eds. Neurology and neurobiology, vol. 18, Senile dementia of the Alzheimer type. New York: Alan R. Liss; 1985:205-218.

43. Robison, S. H.; Munzer, J. S.; Tandan, R.; Bradley, W. G. Alzheimer's disease cells exhibit defective repair of alkylating agent-induced DNA damage. Ann. Neurol. 21:250-258; 1987.
44. Sambrook, J.; Fritsch, E. F.; Maniatis. T. Molecular cloning, a laboratory manual, 2nd ed. Cold Spring Harbor: Cold Spring Harbor Laboratory Press; 1989.

45. Satoh, M. S.; Lindahl, T. Enzymatic repair of oxidative DNA damage. Cancer Res. 54:1899s-1901s; 1994

46. Shigenaga, M. K.; Ames, B. N. Assays for 8-hydroxy-2'deoxyguanosine: A biomarker of in vivo oxidative DNA damage. Free Radic. Biol. Med. 10:211-216; 1991.

47. Shigenaga, M. K.; Park, J. W.; Cundy, K. C.; Gimeno, C. J.; Ames, B. N. In vivo oxidative DNA damage: Measurement of 8-hydroxy-2'deoxyguanosine in DNA and urine by high-performance liquid chromatography with electrochemical detection. Methods Enzymol. 186: 521-530; 1990.

48. Sims, N. R.; Finegan, J. M.; Blass, J. P.; Bowen, D. M.; Neary, D. Mitochondrial function in brain tissue in primary degenerative dementia. Brain Res. 436:30-38; 1987.

49. Sinet, P. M.; Ceballos-Picot, I. Role of free radicals in Alzheimer's disease and Down's syndrome. In: Packer, L.; Prilipko, L.; Christen, Y., eds. Free radicals in the brain; Aging, neurological and mental disorders. Berlin: Springer Verlag; 1992:91-98.

50. Subbarao, K. V.; Richardson, J. S.; Ang, L. C. Autopsy samples of Alzheimer's cortex show increased peroxidation in vitro. J. Neurochem. 55:342-345; 1990.

51. Takeuchi, T.; Nakajima, M.; Ohta, Y.; Mure, K.; Takeshita, T.; Morimoto, K. Evaluation of 8-hydroxydeoxyguanosine, a typical DNA damage, in human leukocytes. Carcinogenesis 15:1519-1523; 1994.

52. Venema, J.; Mullenders, L. H.; Natarajan, A. T.; van Zeeland, A. A.; Mayne, L. V. The genetic defect in Cockayne syndrome is associated with a defect in repair of UV-induced DNA damage in transcriptionally active DNA. Proc. Natl. Acad. Sci. USA 87:4707-4711; 1990.

53. Wallace, D. C. Mitochondrial genetics: A paradigm for aging and degenerative diseases? Science 256:628-632; 1992.

54. Weirich-Schwaiger, H.; Weirich, H. G.; Gruber, B.; Schweiger, M. Correlation between senescence and DNA repair in cells from young and old individuals and in premature aging syndromes. Mutat. Res. 316:37-48; 1994.

55. Zubenko, G. S. Hippocampal membrane alteration in Alzheimer's disease. Brain Res. 385:115-121; 1986. 